\title{
Mapping analysis of saproxylic Natura 2000 beetles (Coleoptera) from the Prigoria-Bengești Protected Area (ROSCI0359) in Gorj County (Romania)
}

\author{
Minodora MANU $U^{1,}$, , Nicolae LOTREAN ${ }^{2}$, Roxana NICOARA ${ }^{1}$, \\ Florian BODESCU ${ }^{3}$, Denisa Lavinia BADIU ${ }^{4}$, Marilena ONETE
}

\begin{abstract}
${ }^{1}$ Institute of Biology Bucharest of Romanian Academy, Department of Ecology, Taxonomy and Nature Conservation, 296 Splaiul Independenței, Bucharest, Romania

${ }^{2}$ Argeș County Museum, Armand Călinescu Street, no. 44, 110047, Piteşti, Argeş County, Romania

${ }^{3}$ Multidimension S.R.L., 3-5 Tg. Frumos St., Bucharest, Romania

${ }^{4}$ University of Bucharest, Centre for Environmental Research and Impact Studies, 1 Nicolae Bălcescu Blvd, Bucharest, Romania

*corresponding author, e-mail: minodora_stanescu@yahoo.com
\end{abstract}

\begin{abstract}
In 2014, an inventory of protected Natura 2000 saproxylic beetles from the Prigoria-Bengeşti protected area in Gorj County (Romania) was made. Four species were identified: Osmoderma eremita (Scopoli, 1763), Lucanus cervus (Linnaeus, 1758), Morimus funereus Mulsant, 1862 and Cerambyx cerdo Linnaeus, 1758. Using GIS mapping analysis, the distribution of these species was established in terms of the habitats described in the Natura 2000 framework. Lucanus cervus occurred over more than half of the Prigoria-Bengești protected area, with an overall area of occupancy of $26.10 \%$. Morimus funereus and Cerambyx cerdo occurred in between $23.21-27.67 \%$ of the area, whereas Osmoderma eremita only occurred in $12.04 \%$ of the ROSCI0359, with area of occupancy by $11.40 \%$. This paper presents the threats to these beetles and summarises some management and conservation issues based on the existing observations and experience at a local level.
\end{abstract}

Key words: abundance, beetle, habitat, mapping, Natura 2000, ROSCI0359 Prigoria-Bengeşti, saproxylic, threat.

\section{INTRODUCTION}

The accession of Romania to the European Union in 2007 required amendment of the relevant EU nature conservation legislation i.e. Council Directive 92/43/EEC of 21 May 1992 on the conservation of natural habitats and of wild fauna and flora (Habitats Directive). Romania's protected area network currently covers $16.76 \%$ of the national territory, and comprises 383 protected areas (Brânzan \& Mănoiu, 2013). One of these protected areas is ROSCI0359 Prigoria-Bengeşti in Gorj County (South Romania), a Site of Community Interest (SCI). Its status as a protected area was declared legally through the Ministry of Environment and Forests Order no. 2387/2011. The Natura 2000 Standard Form for this area mentions three saproxylic beetles (Coleoptera): Lucanus cervus (Linnaeus, 1758); Morimus funereus (Mulsant, 1862) and Osmoderma eremita (Scopoli, 1763). More recent research on the inventory and distribution of these species revealed that one additional saproxylic beetle was present: Cerambyx cerdo Linnaeus, 1758. These four beetle species are endangered or have a protection status. They have been included in Annex II of the EC Habitats Directive and are classified as "European Protected Species". Cerambyx cerdo and Osmoderma eremita are also included in Annex IV of the EC Habitats Directive. All 
these species are also protected by the Romanian national legislation, being included in Annexes 3 and 4A of OUG 57/2007, on the regime of protected natural areas and conservation of natural habitats, wild flora and fauna.

The ecological role of beetles in natural and mature forests ecosystems is well understood. Saproxylic beetles participate in natural decomposition of dead wood, prepare the substrate for colonisation by other species and contribute significantly to the complex ecological interrelationships of deadwood-rich forests. Such species are considered bioindicators for the maturity and ecological stage of their characteristic habitats (mature forests, parks, woodland fringes, orchards) (Bussler et al., 2005; Della Rocca et al., 2014; Stefanelli et al., 2014). New information concerning their community structure, distribution, conservation status of their habitats and threats are very valuable in order to develop management plans for protected areas such as Prigoria-Bengeşti.

Lucanus cervus inhabits mature deciduous forests, especially lowland and medium-altitude oak woodlands (from $1000 \mathrm{~m}$ a.s.l. to $1700 \mathrm{~m}$. a.s.l.), but can also occurs in urban habitats. The larvae are xylophagous, feeding on rotten dead wood at ground level. The imagines of Lucanus cervus usually emerge from the ground in May. The adults are mainly active at dusk and there is a seasonal peak of activity, which can vary from the end of May to the end of June. This species is threatened principally by the decrease in the mean tree age in forests, due to intensive management and over-exploitation - especially in Eastern Europe. These threats result in the loss of dead wood and of old trees which are the habitats required for the species to complete its life cycle (Bardiani et al., 2017).

Morimus funereus is a silvicolous, xylophagous and saproxylic species, its main habitat being deciduous and mixed forests. It lives mainly in old-growth forests or well-structured woodlands, with a medium-high density of dead wood. Larval development takes place in the wood of trunks and stumps and is completed in three or four years under natural conditions. In Romania, adults are active between April and the first half of August, sometimes until late October (Bărbuceanu et al., 2015). One of the main threats to this beetle is the loss of habitat, such as the removal of branches and logs from the forest floor, as well as of standing dead or dying trees. Another threat is the felling and removal of large trees which are deemed too diseased or a danger to forestry operations (Hardensen et al., 2017).

Osmoderma eremita is a large saproxylic beetle associated with hollow old trees with dead wood in European broadleaf woodlands. The seasonal activity of adults is correlated with climatic factors, such as altitude, latitude and habitat type and the adults are active from May to September. Solitary beetle larvae usually occur in hollow but still living, standing trees. They they have also been found in dead standing trees as long as the dead wood is able to retain a suitable degree of moisture (Maurizi et al., 2017). Most of the adult individuals remain within a few hundreds of metres of their natal tree (Chiari et al., 2013). The main threats recognised are the decreasing number of hollow old trees in forests, fragmentation of old-growth forests and lack of connection amongst the habitat trees (Chiari et al., 2013; Maurizi et al., 2017).

Cerambyx cerdo is a polyphagous saproxylic species that lives in deadwood of standing living mature oak trees (Quercus spp.) and other deciduous species such as Fraxinus spp., Salix spp., Ulmus spp., Fagus sylvatica, Platanus spp., Prunus spp. It generally occurs in semi-open wood stands. The larval development mainly takes place in fresh wood of oaks and lasts about 3-4 years, producing an irregular pattern of larval galleries. During the first year, the larvae feed under the bark layer, while 
in the second year, they move deeper into the wood. The adults remain sheltered in their chambers during the winter and emerge between May and August, depending on local climatic conditions relating to altitude and latitude. Over the last century, European populations of Cerambyx cerdo have suffered a dramatic decline in the number of populations and in population sizes in the whole of central Europe, mainly due to a decline in the number of old trees situated in open or semi-open landscapes (Torres-Vila, 2017; Redolfi De Zan et al., 2017).

A bibliographical analysis of scientific papers on the Natura 2000 saproxylic beetles of Gorj County revealed that the first research was made in 1928-1929, by O. Marcu, mentioning some species from karstic areas. Lucanus cervus was identified in the following localities of Gorj County: Bârseşti, Bumbeşti-Jiu, Cheile Bistriţei, Cheile Galbenului, Cheile Sohodolului, Lainici monastery, Pietrele Albe, Târgu Cărbuneşti, Târgu-Jiu, Tismana, Vişina monastery, Zorleşti (Bussler et al., 2005, Chimişliu, 2006, 2007 b, c; Stan, 2013).

Morimus funereus was listed for the following localities: Bumbeşti-Jiu, Cheile Sohodolului, Lainici, Lupşa Valley, Piatra Cloşani, Rânca, Motru Sec, Novaci, Tarniţa, Tismana, Cloşani, Valea Sohodolului, Vişina monastery, Valea Bratcului (Bussler et al., 2005; Chimişliu, 2007a; Serafim et al., 2004; Serafim, 2010).

Survey research in Gorj on Osmoderma eremita, revealed its presence at Cărbuneşti, Cheile Sohodolului and Tismana (Ranius et al., 2005; Bussler et al., 2005; Chimişliu \& Mogoşeanu, 2011). From the taxonomic point of view, Osmoderma eremita sensu lato includes a group of species or subspecies (Audisio et al., 2007). In Romania, the precise species present is Osmoderma barnabita Motschulsky, 1845, although this appears as Osmoderma eremita in standard Natura 2000 descriptions for Romania (Iorgu et al., 2015).

The presence of Cerambyx cerdo was indicated in Bumbeşti, Cheile Bistriţei, Chenia-Dumitra meadows, Lainici, Novaci, Tismana and Vişina Monastery (Bussler et al., 2005; Bobârnac et al., 1999; Serafim et al., 2004; Chimişliu, 2006, 2007 a, b, c).

Studies on coleopterans from Prigoria-Bengeşti protected area were made by Nitzu Eugen in 2010, but the data have not been published. Thus, in the present study, the objectives were to establish for the first time the community structure of Natura 2000 protected saproxylic beetles, their distribution, to map their extend of occurance and area of occupancy and to report threats to the species.

\section{MATERIALS AND METHODS}

\section{Studied area}

The Prigoria-Bengești protected area (ROSCI 0359) is situated in the northeast part of Gorj County, within the Getic Subcarpathians (Fig. 1) and covers 2490 hectares. The altitude varies between $298 \mathrm{~m}$ in the Bucium Valley and $510 \mathrm{~m}$ close to Cârligei Hill. The gradient is $<16 \%$ with an aspect that is predominantly south and south-east.

The climate is temperate-continental, with annual average temperatures between $8^{\circ} \mathrm{C}$ and $10^{\circ} \mathrm{C}$. The average temperature in July is $22^{\circ} \mathrm{C}$ and in January by $-1.5^{\circ} \mathrm{C}$. The annual average precipitation is $700-800 \mathrm{~mm}$. From the pedological point of view, the soils present include: alluvial (2.9\%), argillic (1\%), brown eluvial (podzolic) (49.2\%), brown eumesobasic (4.6\%) and pseudorendsines (42.4\%) (http:// www.natura2000prigoriabengesti.ro/index.php/prezentare-generală). 


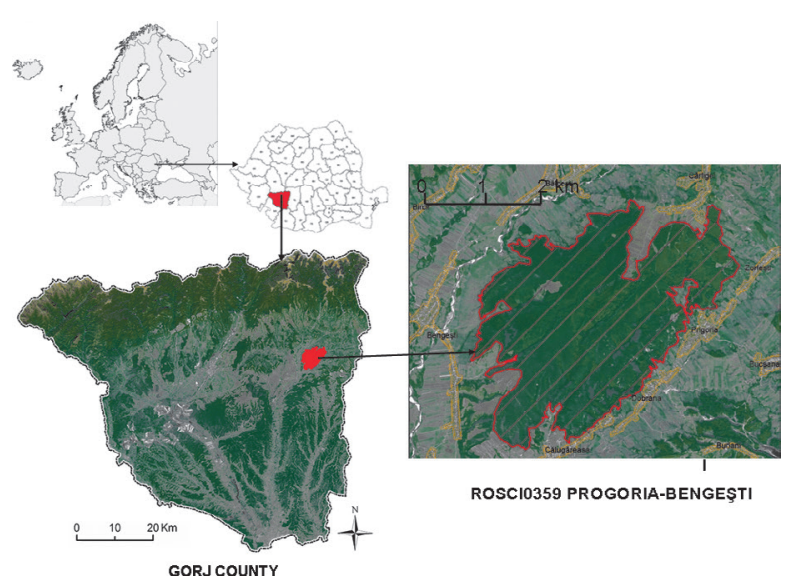

Fig. 1 - Geographical position of the Prigoria-Bengeşti protected area ROSCI 0359 (adaptation after http://www.natura2000prigoriabengesti.ro/harti.html).

The Natura 2000 description for ROSCI 0359 Prigoria-Bengeşti documents the following habitat types (http://www.natura2000prigoriabengesti.ro/index.php/ prezentare-generală), which were investigated in the present study:

- $2.10 \%$ of the total area comprises 9110 Luzulo-Fagetum beech forests (51.59 ha);

- $28.16 \%$ is 9130 Asperulo-Fagetum beech forests (692 ha);

- $51.14 \%$ is 9170 Galio-Carpinetum oak-hornbeam forests (1256.83 ha);

- $4.96 \%$ is 91M0 Pannonian-Balkanic Turkey oak-sessile oak (121.83 ha);

- 5.25\% - 91Y0 Dacian oak-hornbeam forests (129.14 ha);

- $0.75 \%$ - priority habitat $91 \mathrm{E} 0$ alluvial forests with Alnus glutinosa (L.) and Fraxinus excelsior L. (Alno-Padion, Alnion incanae, Salicion albae) (18.43 ha) (Doniță et al., 2005).

Some pine and oak groves $(0.23 \% \equiv 5.58 \mathrm{ha})$; pine and acacia groves $(4.67 \%$ $\equiv 114.85 \mathrm{ha})$ and unproductive land $(2.75 \% \equiv 67.49 \mathrm{ha})$ were also identified (Fig. 2$)$.

\section{Beetle fauna collecting}

The beetle fauna was sampled within the period March-September 2014. As the total area of Prigoria-Bengești is relatively small, all habitats were investigated in the first field trip. After a careful analysis, transects were established in favourable habitats i.e. mature forests (eliminating the young natural regeneration areas less than 5 years old, or unproductive land). For Cerambyx cerdo and Morimus funereus, transects were established mainly in open or semi-open wood stands (Torres-Vila LM, 2017; Redolfi De Zan et al., 2017). For Lucanus cervus transects were established in mature forests, with medium-high quantity of dead wood (Bardiani et al., 2017). For Osmoderma eremita, the study concentrated on old-mature trees with treehollows (Chiari et al., 2013). So as to use a non-destructive way to obtain biological material, two collection methods were used: a) direct observation and identification using transects (for all investigated saproxylic beetles); and b) tree pitfall traps (for Osmoderma eremita) (Bussler et al., 2004, 2005; Ranius et al., 2005; Macagno et al., 2012; Stan \& Nitzu, 2013). 
Ten dry tree pitfall traps were used and 98 transects were investigated. Transects were noted on the map with black points from T1 to T98 (Fig. 2). All transects were investigated only once/study period. The tree pitfalls were checked every four days.

The length of each transect was 500 metres with a width of 50 metres. Transects were chosen taking account of the preferred habitat of the saproxylic beetles investigated: deciduous natural or planted mature forest, riparian areas with forests. Dead and live adults, exoskeletons or fragments were all counted. After identification and counting, the live individuals were released.

For Osmoderma eremita, an inspection was made of reachable cavities for larvae, or remains of adult beetles and larval faecal pellets in the wood mould. The dry tree pitfall trapping (PT) was carried out during summer (July-August), when the adults were active (Fig. 2). The pitfall traps were placed in the hollows of living, standing trees (Fagus sylvatica L., Quercus cerris L., Carpinus betulus L.). The traps were checked at every second day (Ranius, 2002; Martin, 2002; Ranius et al., 2005). The observation points, transects and geographical coordinates were recorded with Garmin eTrex GPS. At the same time the transect number, the toponymy, altitude, the habitat, microhabitat and development stage were recorded (Tab. 1). In order to provide some conservation measures for these four beetles, any threats were noted, using the classification of Salafsky et al., 2008. For morphological details a Zeiss stereomicroscope and a Sony, full HD 1080 digital camera were used.

\section{GIS mapping}

In order to map the spatial distribution of the four species in the PrigoriaBengeşti Natura 2000 site, we used presence data gathered with GPS techniques from field observations.

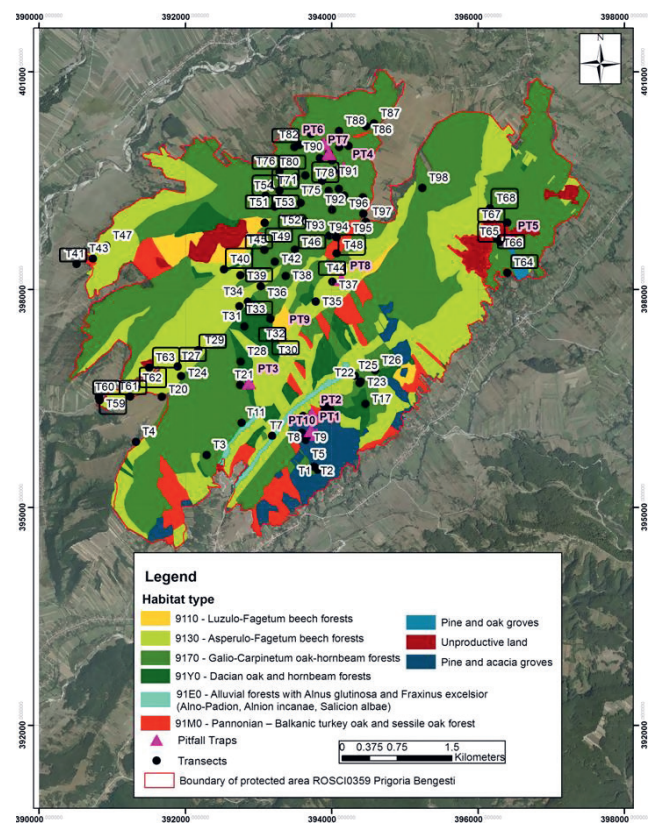

Fig. 2 - The investigated transects and pitfall traps within the Prigoria-Bengeşti protected area. Transects framed with black squares mark the trails and forest roads. 


\section{$\frac{\sqrt{3}}{\frac{\pi}{2}}$}

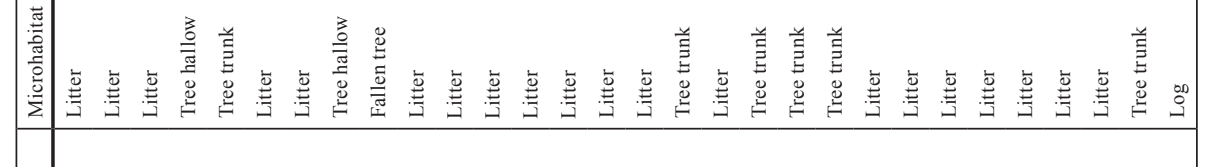

อ

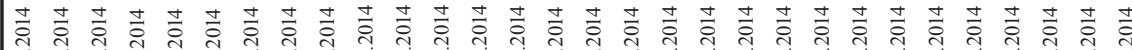

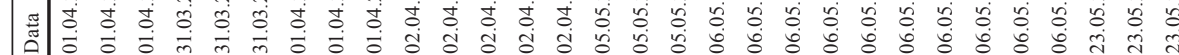

i

$\stackrel{1}{1}$

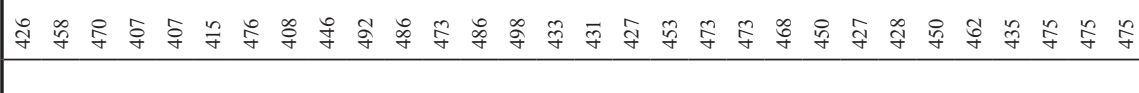

$\Xi$

ลิ

है

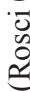

ฮ

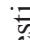

8

承

욜

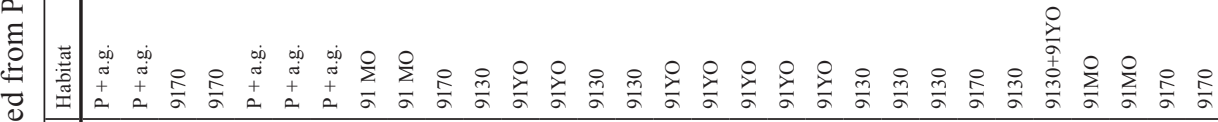

몸

跑

ஓ

๖ำ

鱼

$\frac{9}{7}$

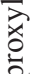

要

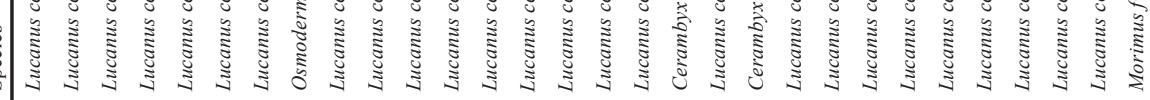

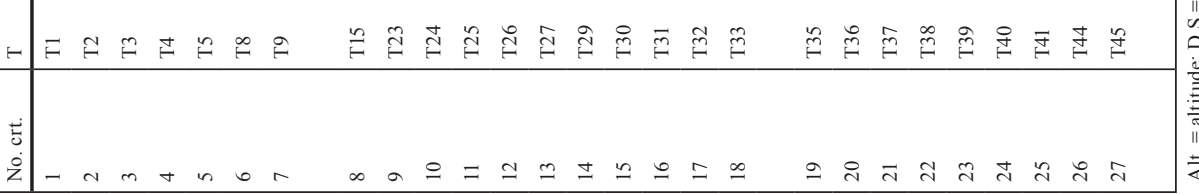


$\sqrt{3}$
0
0
0
0
0
0
0
0
0

(5)

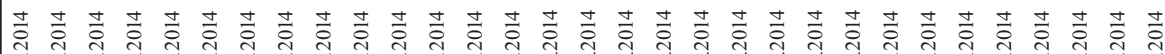

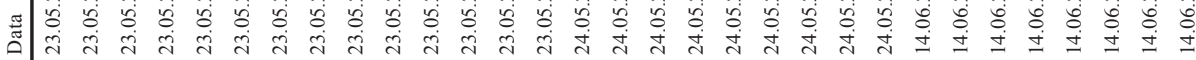

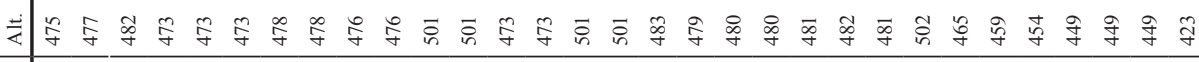

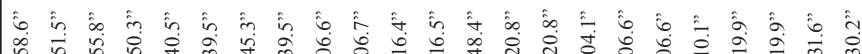

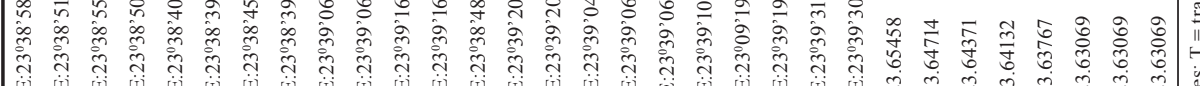

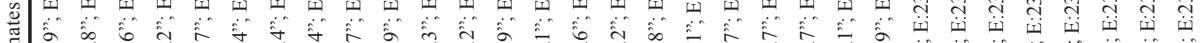

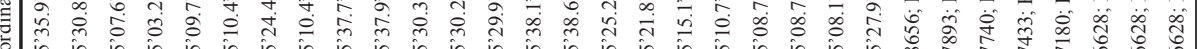

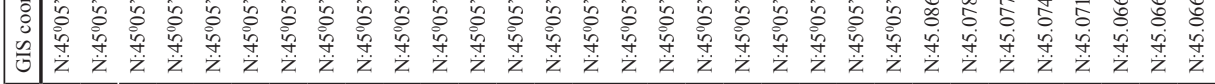

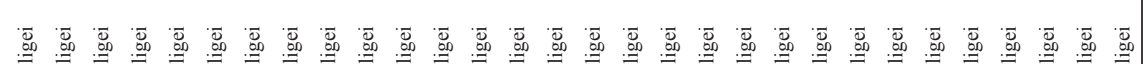

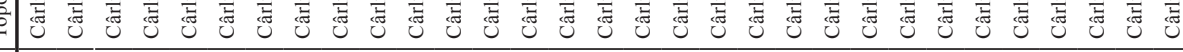

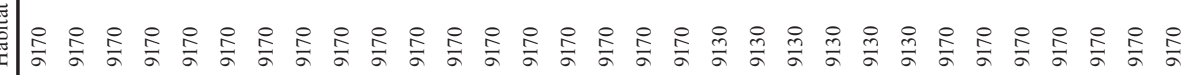

บุ.

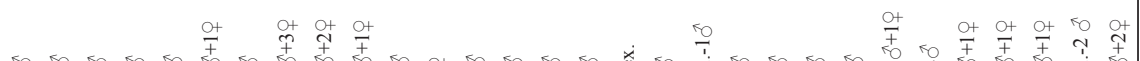

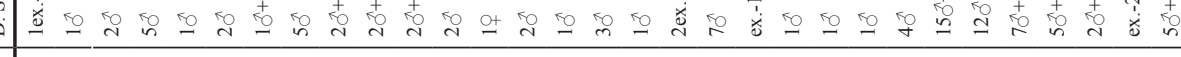

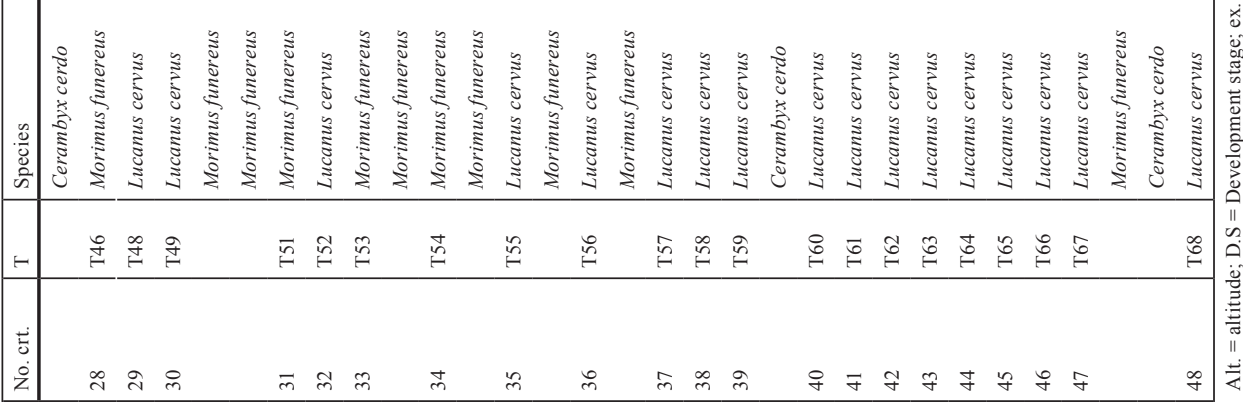




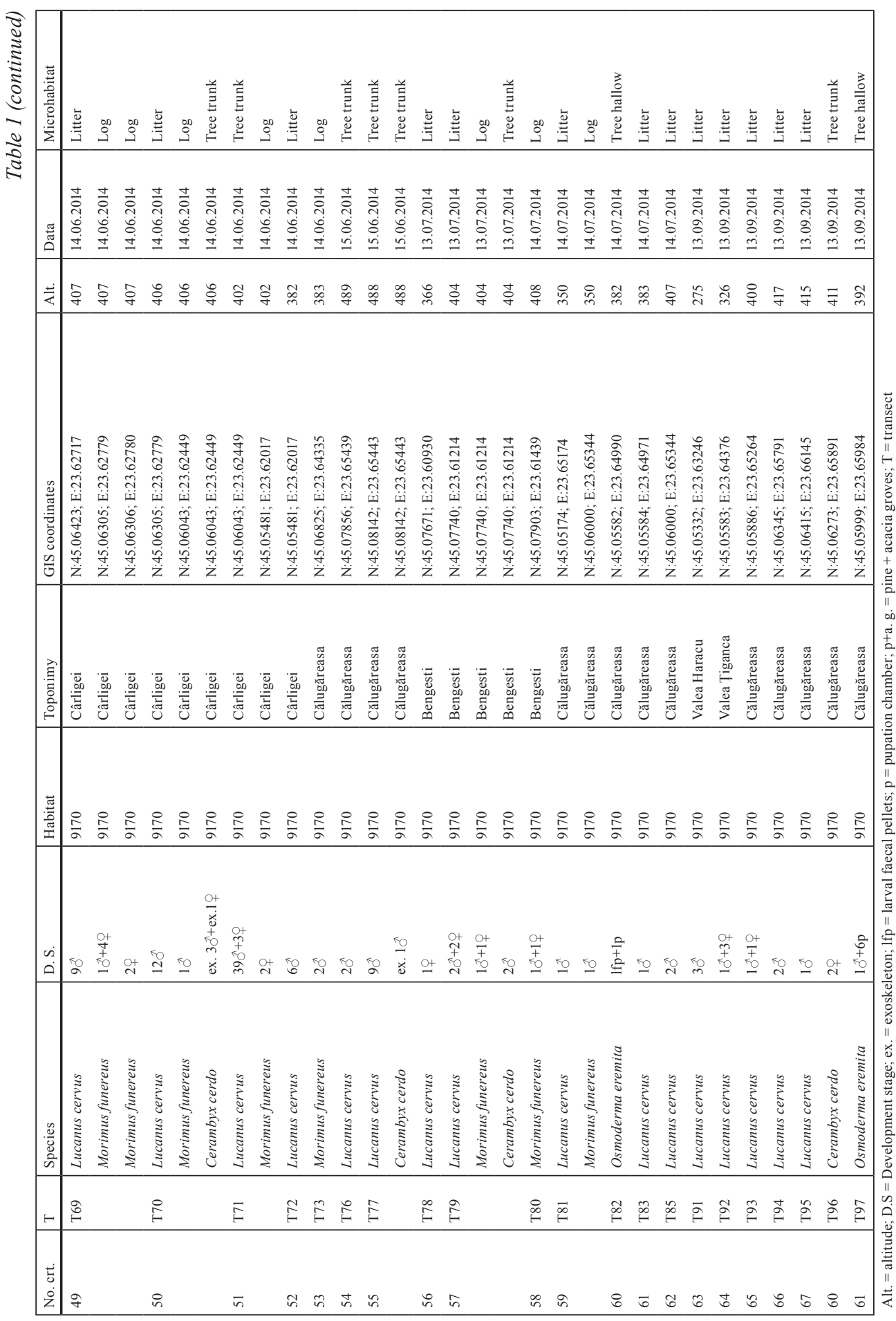


According to IUCN criteria and to Council Directive 92/43/EEC, the most commonly used method for determining species distribution ('limits of distribution' or 'field guide' maps) is based on the following parameters:

- extend of occurrence $(\mathrm{EOO}) \equiv$ area that contains all known, inferred or projected sites of occurrence, also known as Minimum Convex Polygon - MCP; and

- area of occupancy $(\mathrm{AOO}) \equiv$ the area within its extent of occurrence, which is occupied by a taxon, excluding cases of vagrancy (Burgman \& Fox, 2003).

Both EOO and $\mathrm{AOO}$ are calculated on the EEA grid by $1 \mathrm{x} 1 \mathrm{~km}$ (EEA reference grid 2015) proposed by the European Community for the reporting of article 17 of the Habitats Directive. We used Ramas Red List 3.0 (Akçakaya \& Root, 2007) to calculate the indicators that describe the home range of the four species in the Prigoria-Bengești site: Extend of Occurrence (EOO) and Area of Occupancy (AOO) - indicators that were mapped using ArcGIS Desktop 10.1 (ESRI, 2012).

\section{RESULTS}

Lucanus cervus was identified in 59 transects, with a total abundance of 228 individuals, and a sex ratio of $192{ }^{\top}: 36$. Transects in which the species was identified were located in various habitats: 9170 Galio-Carpinetum oak-hornbeam forests (55.93\% of the total number of transects); 9130 Asperulo-Fagetum beech forests (20.33\%); 91 Y0 Dacian oak-hornbeam forests (8.47\%); 91M0 Pannonian-Balkanic Turkey oak-sessile oak (5.08\%); pine and acacia groves (8.47\%) and a mixture of 9130 Asperulo-Fagetum beech forests and $91 Y 0$ Dacian oak-hornbeam forests (1.69\%) (Tab. 1).

All specimens (males and females) were identified in forest ecosystems with Quercus cerris L., Quercus petraea L., Fagus sylvatica L. and Carpinus betulus L., at an average altitude of 435.56 metres. The species was found from end of April to September (exoskeletons and adults, 2014). The highest numerical densities were obtained in forests with $Q$. cerris L. and $Q$. petraea L. (T64: 16 individuals; T69: 9 individuals; T70: 12 individuals; T71: 43 individuals; and T77: 9 individuals); in mixed forests with $F$. sylvatica L. and C. betulus L. (T72: 6 individuals). The species was observed mainly on litter or tree trunks.

After GIS mapping analysis, the EOO and AOO of the Lucanus cervus were defined. The EOO was estimated as $14.33 \mathrm{sqkm}$ (1433 ha), which represents $57.55 \%$ of the total area of Prigoria-Bengeşti. The AOO was estimated as $6.5 \mathrm{sqkm}(650 \mathrm{ha})$, representing $26.10 \%$ of the SCI (Fig. 3A).

Morimus funereus was observed in 16 of the transects investigated, with a total of 47 individuals and a sex ratio of $29{ }^{\lambda}: 18$. All these transects were situated in 9170 Galio-Carpinetum oak-hornbeam forests, with an average altitude of $444.41 \mathrm{~m}$ (Tab. 1). Specimens were found on logs of Q. cerris L., Q. petraea L., C. betulus L. or F. sylvatica $\mathrm{L}$. The highest numerical densities were obtained in T53 (9 individuals), T54 (5 individuals) and T69 (7 individuals) (Table 1). The species was found from May to September, 2014. The EOO was defined as $5.91 \mathrm{sqkm}(591 \mathrm{ha})$ i.e. $23.73 \%$ of the total area of the SCI, whilst the AOO was $5.86 \mathrm{sqkm}$ (586 ha), representing $23.53 \%$ of the studied area (Fig. 3B).

Focussing on the structure of the Cerambyx cerdo populations, 22 individuals were identified in 9 transects, with a sex ratio of 18 : $: 4$. Most individuals occurred in 9170 Galio-Carpinetum oak-hornbeam forests, on trunks of Q. cerris L. and $Q$. petraea L. - indeed, $80 \%$ of transects where this species was identified were located in this habitat. However, some examples of Cerambyx cerdo were also found in 91Y0 
A

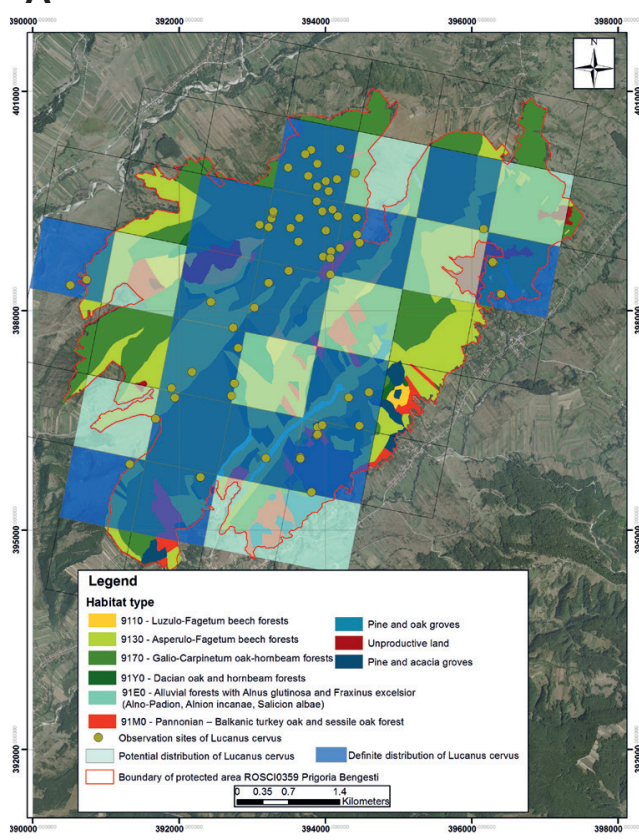

C

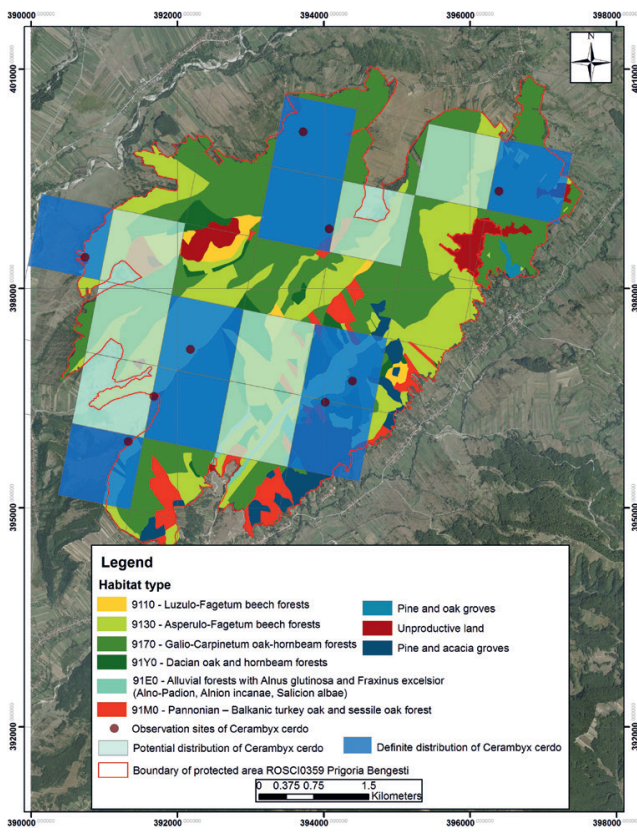

B

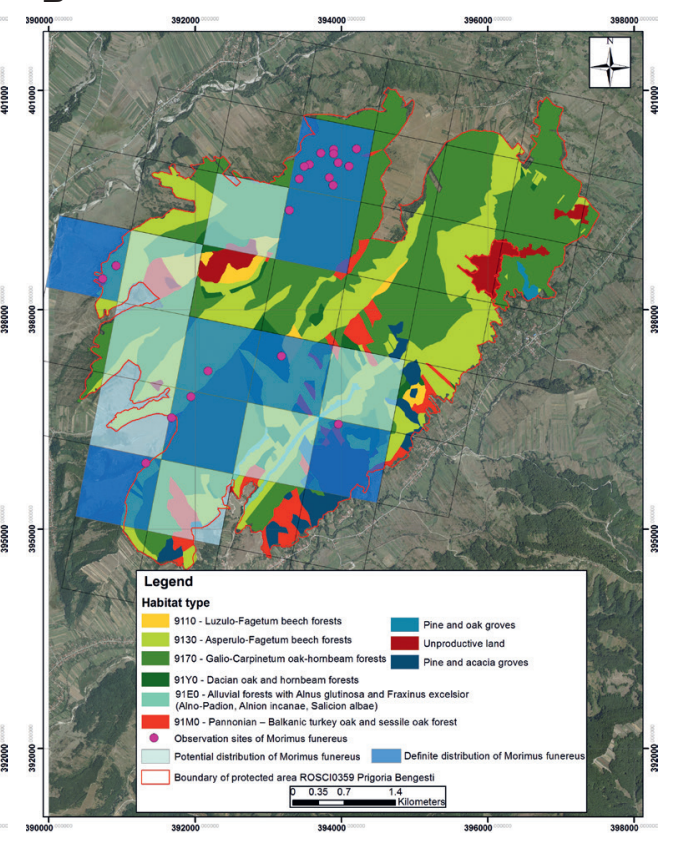

D

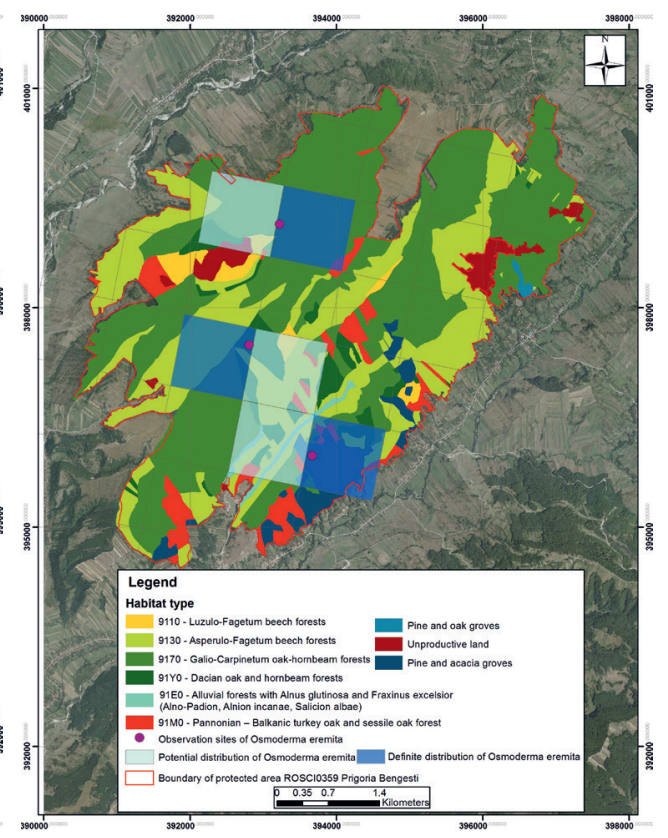

Fig. 3 - The observation sites, defined and potential distributions of saproxylic Natura 2000 beetles investigated in the Prigoria-Bengeşti protected area (ROSCI 0359) ( $\mathrm{A}=$ Lucanus cervus, $\mathrm{B}=$ Morimus funereus, $\mathrm{C}=$ Cerambyx cerdo, $\mathrm{D}=$ Osmoderma eremita $)$. 
Dacian oak-hornbeam forests (Tab. 1). The species was found from May to September, 2014. After map-processing, the EOO was evaluated as $6.89 \mathrm{sqkm}$ (689 ha) i.e. $27.67 \%$ of the total Prigoria-Bengești SCI and the AOO was calculated as $5.78 \mathrm{sqkm}$ (578 ha), equivalent to $23.21 \%$ of the area investigated (Fig. 3C).

Although ten tree pitfall traps were placed in tree-hollows, no adult specimens of Osmoderma eremita were captured with this method. Direct observations identified one male, larval faecal pellets and seven pupation chambers. These records were for hollows of still living, standing trees of $Q$. cerris L., Q. petraea L. and F. sylvatica L. (over 80 years old). One observation point was located in 91M0 Pannonian-Balkanic Turkey oak-sessile oak habitat and the others two in 9170 Galio-Carpinetum oakhornbeam forests (Tab. 1). An adult-female was identified in August, 2014. Using GIS techniques, its EOO was estimated as $3 \mathrm{sqkm}$ (300 ha), equivalent to $12.04 \%$ of the SCI, and the AOO represents 2.84 sqkm or $11.40 \%$ of the studied area (Fig. 3D).

\section{DISCUSSION}

Lucanus cervus (Linnaeus, 1758) is a silvicolous, xylodetriticolous, succicolous and saproxylic species. Specimens from the Prigoria-Bengeşti SCI were observed on trunks of Quercus cerris L., Q. petraea L., Fagus sylvatica L., Carpinus betulus L., but also in litter (Fig. 4B). From the saproxylic beetles of community interest, Lucanus is the most frequent species on this site. It is distributed over five of the six Natura 2000 habitats recorded in the SCI, and its EOO extends over more than half of the Prigoria-Bengești site. This high recorded numerical abundance is due to the presence of many favourable habitats. However, some threats, which in future may cause a decreased abundance, were identified: forest thinning/cleaning cuts associated with extraction of timber derived mainly from old trees; and the high number of paths and trails (Fig. 4).

Morimus funereus Mulsant, 1862 is a stenotopic, silvicolous, xylodetriticolous, xylophagous and saproxylic species. According to IUCN criteria, this beetle was considered a vulnerable species (Nieto \& Alexander, 2010). It was identified on logs from one single type of habitat: 9170 Galio-Carpinetum oak-hornbeam forests, which occupy more than half of the Prigoria-Bengești area, where the trees are over 70 years old (Fig. 4C, 4D). The EOO and $\mathrm{AOO}$ of Morimus funereus cover almost a quarter of the SCI. Because of their inability to fly, adults of the genus Morimus are poor dispersers and therefore suffer particularly from habitat fragmentation (Thomas, 2000; Chiari et al., 2013). The high number of forest roads in Prigoria-Bengeşti SCI represents an important threat to Morimus funereus populations (Fig. 5). This species was found on logs, in the vicinity of small wood exploitation (where about 5-6 trees had been cut). This observation is in concordance with results obtained by other specialists, which demonstrate that this beetle is attracted to fresh deadwood at ground level (fallen logs, stumps or other wood), where it lays eggs (Vrezec et al., 2012; Chiara et al., 2013). These piles could act as ecological traps if they are chipped and/or removed before the beetles have emerged. If not removed, they can function as an important substrate for many other saproxylic organisms (Chiara et al., 2013). On the other hand, an increased rate of tree cutting would modify the forest microclimate, influencing the life cycle of Morimus funereus (even disturbance in the metabolism of larvae) or reduce its food source (Djordjević et al., 1995).

Cerambyx cerdo Linnaeus, 1758 is a stenotopic, pholeophilic, xylodetriticolous, lignicolic, xylophagous and saproxylic species. According to IUCN criteria, it is considered vulnerable (Nieto \& Alexander, 2010). It was recorded on tree trunks of 

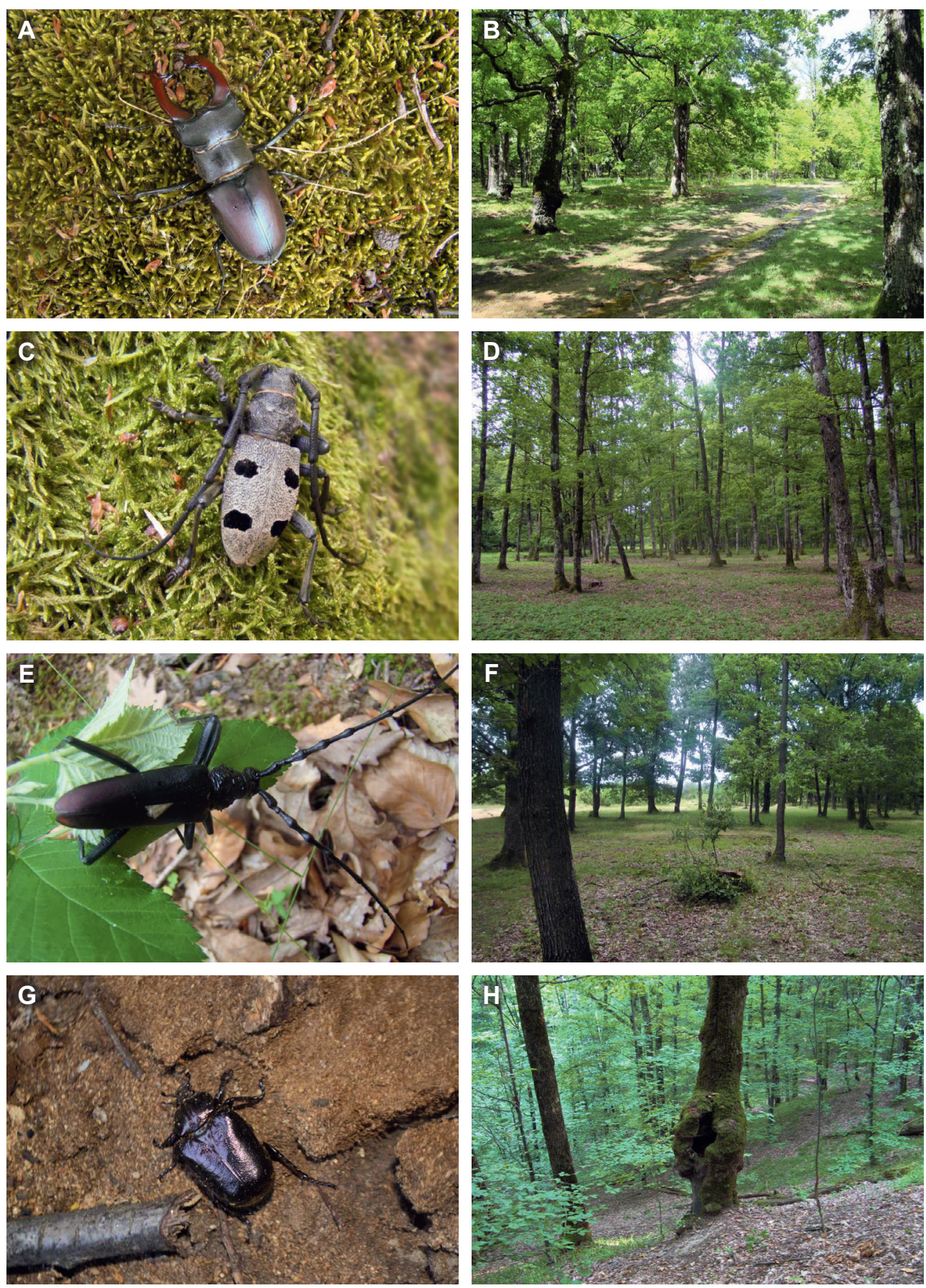

Fig. 4 - Saproxylic Natura 2000 bark beetles investigated in the Prigoria- Bengești protected area and their habitats (A, B = Lucanus cervus, $\mathrm{C}, \mathrm{D}=$ Morimus funereus, $\mathrm{E}, \mathrm{F}=$ Cerambyx cerdo, $\mathrm{G}, \mathrm{H}$ 
Q. cerris L. and Q. petraea L. from sunny places, situated mainly on forest edges (Fig. 4E, 4F). The EOO and AOO are comparable with those of Morimus funereus, representing almost a quarter of the Prigoria-Bengeşti area. These habitats are characterised by the presence of open spaces, with sun-exposed trees. Research showed that the species richness and number of red-listed saproxylic beetles are significantly higher in sun-exposed trees, even though larval development of Cerambyx cerdo takes place in the interior of the trunk (Buse et al., 2007). As mentioned above, the main threats to Cerambyx cerdo in Prigoria-Bengeşti are forest thinning and cleaning cuts (when dead and dying wood is often removed) and the presence of many forest paths (Fig. 5). On one hand, creating more forest trails will lead to habitat fragmentation. Relationships between dead wood connectivity and beetle richness existed only at a local scale (50-150 m). Small fragmented populations may also be affected by the low dispersal ability of this beetle, as it hinders its ability to colonise new, suitable habitats (Schiegg, 2000; Buse et al., 2007). On the other hand, however, active management that prevents canopy closure is crucial to survival of Cerambyx cerdo (Albert et al., 2012).

Osmoderma eremita (Scopoli, 1763) is a stenotopic, pholeophilic, silvicolous, xylo-detriticolous, phytophagous and saproxylic species. According to IUCN this species is vulnerable - Bern-II; FFH-II, IV (Nieto \& Alexander, 2010). In the PrigoriaBengeşti SCI, it was found in old forests with $Q$. cerris $\mathrm{L}$. and $Q$. petraea $\mathrm{L}$, similar to elsewhere in Europe. Oaks are the trees mainly used by this species, followed by lime (Tilia spp.), willow (Salix spp.), beech (Fagus sylvatica L.) and fruit trees (Prunus spp., Pyrus spp., Malus domestica Borkh, 1803). Osmoderma eremita is still found in some remnants of natural forest, but is mainly observed on land that has long been used by humans, such as pasture woodlands, hunting parks, avenues, city parks and trees around agricultural fields and along streams (Ranius, 2002; Ranius et al., 2005; Audisio et al., 2007). The main threats to this species were: forest thinning/cleaning cuts associated with extraction of old/mature trees with hollows from the forest; and the presence of many forest roads, paths or trails (Fig. 5).

According to Ranius et al. 2005, a conservation plan for Osmoderma eremita should include three aspects that are of general importance in Europe today: preservation of remnants of natural forests with old, broad-leaved trees; preservation and restoration of habitats related to traditional agricultural landscapes; and preservation of remaining "islands" of nature in urban areas.

Considering the threats to all four investigated saproxylic Natura 2000 beetles from the Prigoria-Bengeşti SCI, we concluded that forest thinning associated with timber cutting and extraction of old/ or mature trees, could change the forest microclimate, affecting the development cycle of these invertebrates. At the same time trophic resources for the beetles will diminish. In the extensively managed forests, regular cutting of trees should be implemented to create artificial stumps, in order to assure a continuity of deadwood and, in the meantime, increase the number and width of openings in the forest. Moreover, prolonging rotation times can assure the presence of deadwood at intermediate or later stages of decay (Schiegg, 2000; Della Rocca et al., 2014).

The number of beetle taxa was significantly and positively related to the diameter and the state of trunks, the percentage of dead wood inside the crown, the number of large pieces of dead wood within the crown, the accumulated length $(\mathrm{m})$ of large pieces of dead wood on the ground and the number of large pieces of dead wood on the ground (Schiegg, 2000; Bussler et al., 2005; Buse et al., 2007; Sirami et al., 2008). 

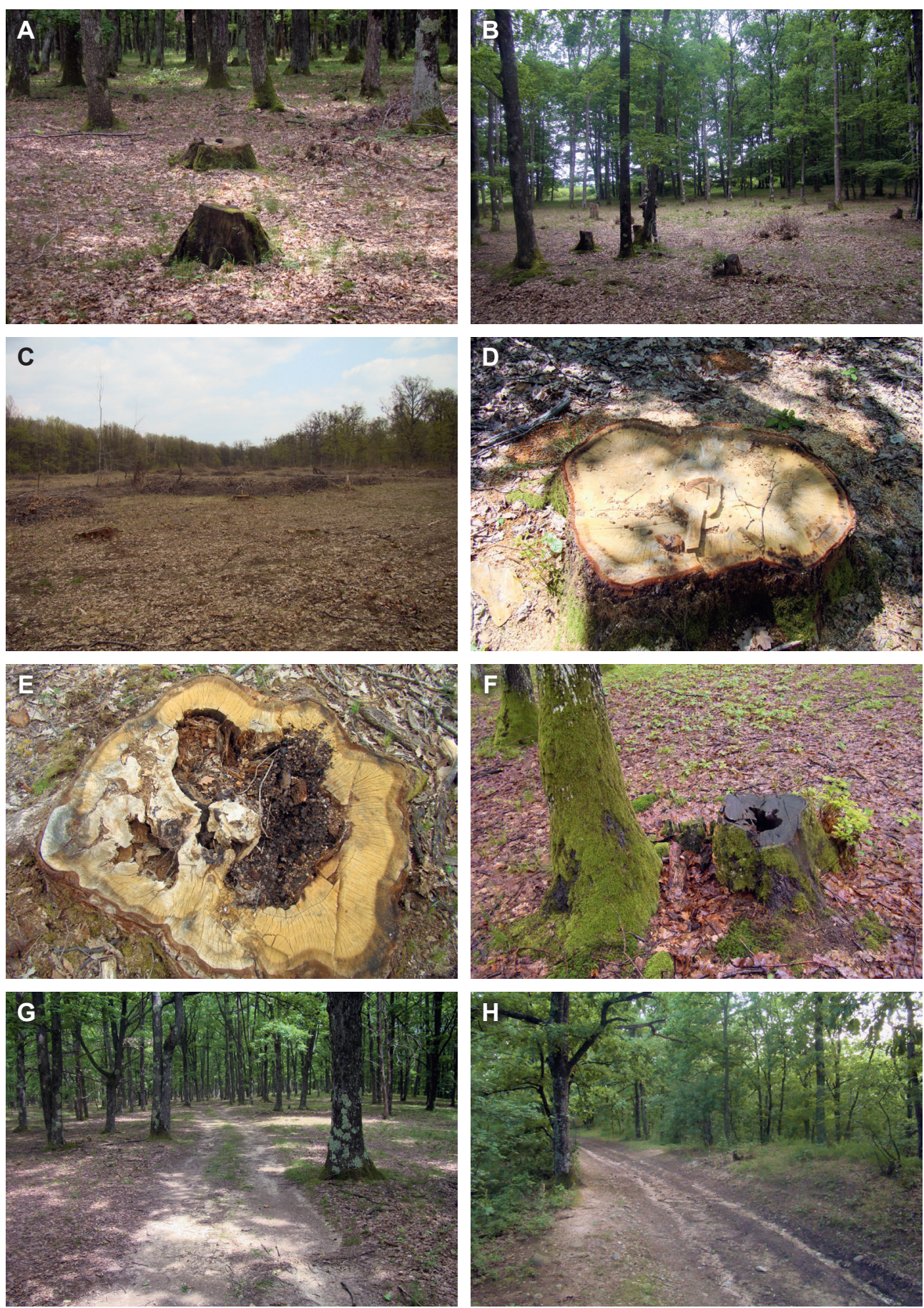

Fig. 5 - The main threats of the saproxylic Natura 2000 bark beetles investigated in the PrigoriaBengeşti protected area. 
Complex studies, made by Zaponni et al. (2017), revealed that carefully designed hiking trails could be beneficial to conservation as they have the potential to boost sustainable natural areas and enhance public awareness. However, in the PrigoriaBengești area, the excessive number of forest paths and trails, randomly generated, could lead to habitat loss and/or fragmentation, as well as soil erosion and facilitating access of humans and machines to natural, undisturbed habitats (Thomas, 2000).

Additional anthropogenic disturbance includes the grazing of forest stands by goats, sheep and cows in the vicinity of the grasslands. Studies revealed that grazing on a large spatial scale and at low intensity, with large herbivores, such as horses or cattle, promises the best impact to generate suitable landscape and tree-level conditions of oaks, especially for the occurrence of Cerambyx cerdo. Because of their ability to feed on the lower canopy branches and leaves, large herbivores are important for opening the trunks to the sunlight. Surprisingly, grazing seems to be important for oak recruitment (Buse et al., 2007). It is essential to pay attention to this anthropic factor, because unmanaged grazing can quickly and easily transform into overgrazing.

Due to the fact that most ( $>95 \%)$ of the investigated forest within the PrigoriaBengeşti SCI is private property, there is a risk that these threats will increase in their intensity. For this reason, a suitable forestry management plan, which includes strict control of tree cutting and of the timber volume to be extracted, should represent an efficient tool for saproxylic Natura 2000 beetle conservation.

\section{Conclusions}

Three saproxylic Natura 2000 beetle species were identified in PrigoriaBengești SCI, in concordance with the Standard Form: Osmoderma eremita (Scopoli, 1763), Lucanus cervus (Linnaeus, 1758) and Morimus funereus Mulsant, 1863. At the same time, another species with conservative value was found: Cerambyx cerdo Linnaeus, 1758. All beetle species are protected according to both national and European legislation.

The highest numerical abundance was recorded for Lucanus cervus, followed by Morimus funereus, Cerambyx cerdo and Osmoderma eremita. The Natura 2000 habitat 9170 Galio-Carpinetum oak-hornbeam forests was the most favourable type of ecosystem for the investigated beetle species.

Their EOO and AOO varied, depending on habitat preferences, classified according to Natura 2000 criteria. More than half of the area of the Prigoria-Bengeşti SCI represented EOO for Lucanus cervus; between 23.21-27.67\% was considered as EOO and AOO for Morimus funereus and Cerambyx cerdo. Osmoderma eremita had the smallest proportion of ROSCI 0359 that represented EOO (12.04\%) and AOO $(11.40 \%)$.

All identified beetles of community interest were silvicolous, xylodetriticolous and saproxylic species, found in mature/old deciduous forest, especially in Dacian forest with Quercus petraea L., Fagus sylvatica L. and Carpinus betulus L., with Carex pilosa Scop., and were found in different microhabitats: litter, tree trunks, logs, tree hollows. The local investigations revealed two major threats to the beetles e.g. forest thinning associated with timber cutting and extraction; and the high number of paths and trails. Due to the insular nature of the Prigoria-Bengeşti SCI, the appearance of any new disturbance factors or increased intensity of those mentioned above, will had a negative impact on the populations of the investigated saproxylic beetles (decreasing the number of individuals, modification of the sex ratio, limiting or elimination of the young generations). This confirms the need for a proper forest management, which 
could comprise a strict control of tree cutting and of the timber volume that may be extracted, the limiting the number of roads, paths and trails and grazing surveillance.

\section{ACKNOWLEDGEMENTS}

This work was supported by the Institute of Biology Bucharest of Romanian Academy, under Grant RO1567-IBB01/2017 and by the POS MEDIU- code SMIS-CSNR 43263. The authors wish to thank Owen Mountford (NERC (National Environment Research Council) Centre for Ecology and Hydrology, UK, for advice on the English text and other valuable information.

\section{REFERENCES}

ALBERT, J., M. PIATEK, L. CIZEK (2012) Vertical stratification and microhabitat selection by the Great Capricorn Beetle (Cerambyx cerdo) (Coleoptera: Cerambycidae) in open-grown, veteran oaks. European Journal of Entomology, 109: 553-559.

AKÇAKAYA, H. R., W. ROOT (2007) RAMAS ${ }^{\circledR}$ Red List Professional: Spatial and Temporal Data Analysis for Threatened Species Classifications Under Uncertainty. Applied Biomathematics, Setauket, New York.

AUdisio, P., H. BRUSTEL, G.M. CARPANETO, G. COLETTI, E. MANCINI, E. PIATTELLA, M. TRIZZINO, M. DUTTO, G. ANTONINI, A. DE BIASE (2007) Updating the taxonomy and distribution of the European Osmoderma, and strategies for their conservation (Coleoptera, Scarabaeidae, Cetoniinae). Fragmenta entomologica Roma, 39 (2): 29-273.

BARDIANI, M., S. CHIARI, E. MAURIZI, M. TINI, I. TONI, A. ZAULI, A. CAMPANARO, G.M. CARPANETO, P. AUDISIO (2017) Guidelines for the monitoring of Lucanus cervus. In: Cappaneto G.M., P. Audisio, M.A. Bologna, P.F. Roversi, F. Mason (Eds) Guidelines for the Monitoring of the Saproxylic Beetles protected in Europe. Nature Conservation 20: 37-78.

BĂRBUCEANU, D., M. NICULESCU, V. BORUZ, L. NICULESCU, C. STOLERIU, A. URSU (2015) Protected saproxylic Coleoptera in "the Forests in the southern part of the Cândești Piedmont", a Romanian Natura 2000 Protected Area. Analele Universităţii din Craiova, seria Agricultură Montanologie Cadastru (Annals of the University of Craiova - Agriculture, Montanology, Cadastre Series) 45: 18-25.

BRÂNZAN, T., T. MÂNOIU (2013) Catalogul habitatelor, speciilor și siturilor Natura 2000 în România. Editura Fundaţia Centrul Naţional pentru Dezvoltare Durabilă, Bucureşti Exclus Prod. 784 pp. (in Romanian)

BOBÎRNAC, B., O. MARCU, C. CHIMIŞLIU (1999) Cu privire la sistematica şi ecologia coleopterofaunei din zona subcarpatică a Olteniei în ultimii 70 de ani (1928-1998). Muzeul Olteniei Craiova. Oltenia. Studii şi Comunicări Ştiinţele Naturii, Craiova, 15: 83-95 (in Romanian).

BURGMAN, M. A., J.C. FOX (2003) Bias in species range estimates from minimum convex polygons: implications for conservation and options for improved planning. Animal Conservation forum, 6 (1): 19-28.

BUSE J., B. SCHRODER, T. ASSMANN (2007) Modelling habitat and spatial distribution of an endangered longhorn beetle - A case study for saproxylic insect conservation. Biological Conservation, 137: $372-381$.

BUSSLER, H., J. MÜLLER, V. DORKA (2005) European natural heritage: the saproxylic beetles in the proposed Parcul National Defileul Jiului. Analele ICAS, 48: 3-19.

BUSSLER, H., J. MÜLLER, U. SIMON (2004) Erfassung xylobionter Käfer in Waldökosystemen - Ein Methodenvergleich unter besonderer Berücksichtigung der Kronenfauna. Naturschutz und Landschaftsplanung. Stuttgart, 36(7): 197-201 (in German).

CHIARI, S., M. BARDIANI, A. ZAULI, S. HARDERSEN, F. MASON, L. SPADA, A. CAMPANARO (2013) Monitoring of the saproxylic beetle Morimus asper (Sulzer, 1776) (Coleoptera: Cerambycidae) with freshly cut log piles. Journal of Insect Conservation, 17: 1255-1265.

CHIMIŞLIU, C (2006) Insecte protejate de interes comunitar din potenţialul Parc Natural Nordul Gorjului. Studii şi Comunicări Ştiinţele Naturii, 22: 178 - 184 (in Romanian).

CHIMIŞLIU, C.(2007a) Contributions in getting to know the diversity of the Cerambycide fauna (Insecta: Coleoptera: Cerambycidae) from the "Nordul Gorjului" Potential Natural Park, County Gorj, Romania. Muzeul Civilizaţiei Dacice şi Romane, Deva. Sargetia, Acta Musei Devensis, Series Scientia Naturae, 20: 154-161.

CHIMIŞLIU, C. (2007b) Contribuții la cunoaterea diversităţii faunei de coleoptere (Insecta: Coleoptera) din Cheile Galbenului - Judeţul Gorj, România. Buletin Ştiinţific, Revista de Etnografie, Ştiinţele Naturii şi Muzeologie. Serie nouă - Ştiinţele Naturii, 6(19): 34-45 (in Romanian). 
CHIMIŞLIU, C. (2007c) Contribution to the knowledge of the Romanian fauna of Lucanidae (Coleoptera: Scarabaeoidea). Analele Ştiinţifice ale Universității “Al. I. Cuza” Iaşi, Biologie animală, 53: 97-102.

CHIMIŞLIU, C., G. MOGOŞEANU (2011) New data on Cetoniidae species (Coleoptera: Scarabaeoidea) preserved in the patrimony of the Oltenia Museum Craiova (Romania). Travaux du Muséum National d'Histoire Naturelle "Grigore Antipa", 54(1): 105-114.

DELLA ROCCA, F., S. STEFANELLI, C. PASQUARETTA, A. CAMPANARO, G. BOGLIANI (2014) Effect of deadwood management on saproxylic beetle richness in the floodplain forests of northern Italy: some measures for deadwood sustainable use. Journal of Insect Conservation, 18(1): 121-136.

DJORDJEVIĆ, S., J. IVANOVIĆ, M. JANKOVIĆ-HLADNI (1995) Effect of dietary regime and stressful temperatures on Morimus funereus larval metabolism. Comparative Biochemistry and Physiology. Part A: Physiology, 111(1): 139-145.

DONIŢĂ, C, A. POPESCU, M. PAUCĂ COMĂNESCU, S. MIHĂILESCU, I. BIRIŞ (2005) Habitatele din România. Editura Silvică, Bucharest. 496 pp. (in Romanian).

HARDENSEN, S., M. BARDIANI, S. CHIARI, M. MAURA, E. MAURIZI, P.F. ROVERSI, F. MASON, M.A. BOLOGNA (2017) Guidelines for the monitoring of Morimus asper funereus and Morimus asper asper. Nature Conservation, 20: 205-236.

IORGU, I. Ș. (Ed.), V. SURUGIU, V. GHEOCA, O.P. POPA, L.O. POPA, I. SÎRBU, L. PÂRVULESCU, E.I. IORGU, C.O. MANCI, L. FUSU, M. STAN, M.M. DASCĂLU, L. SZÉKELY, M. STĂNESCU, T.C. VIZAUER (2015) Ghid sintetic pentru monitorizarea speciilor de nevertebrate de interes comunitar din România. Asocierea S.C. Compania de Consultanţă şi Asistenţă Tehnică S.R.R. şi S.C. Integra Trading S.R.L., Bucharest, 159pp. (in Romanian)

MACAGNO, A. L. M., M. GOBBI, A. FRANCESCHINI, V. LENCIONI (2012) New record of Osmoderma eremita (Scopoli, 1763) (Coleoptera: Cetoniidae) in chestnut trees in Trentino (Eastern Italian Alps). Studi Trentini di Scienze Naturali, 92: 37-41.

MARCU, O. (1928) Contribuţii la cunoaşterea coleopterelor Olteniei. Arhivele Olteniei, 7 (39-40): 473-487 (in Romanian).

MARCU, O. (1929) Contribuţii la cunoaşterea faunei Olteniei. Arhivele Olteniei, 8 (45-46): 474-479 (in Romanian).

MARTIN, O. (2002) Kortlægning af eremitten Osmoderma eremita i Danmark 1999. In: S. Pihl, K. Laursen, (Eds.) Kortlægning af arter omfattet af EF-Habitatdirektivet 1997-2000. Naturovervågning. Arbejdsrapport fra DMU, Danmarks Miljøundersøgelser (Miljøministeriet), Copenhagen, 167: 58-78. (in Dutch)

MAURIZI, E., A., CAMPANARO, S. CHIARI, M. MAURA, F. MOSCONI, S. SABATELLI, A. ZAULI, P. AUDISIO, G.M., CARPANETO (2017). Guidelines for the monitoring of Osmoderma eremita and closely related species. Nature Conservation, 20: 79-128.

NIETO, A., K.N.A. ALEXANDER (2010) European red list of saproxylic beetles. European Commission, European Union, IUCN-Species Programme, IUCN-SSC, 44 p.

RANIUS, T. (2002) Osmoderma eremita as an indicator of species richness of beetles in tree hollows. Biodiversity Conservation, 11: 931-941.

RANIUS, T., L.O. AGUADO, K. ANTONSSON, P. AUDISIO, A. BALLERIO, G.M. CARPANETO, K. CHOBOT, B. GJURAŠIN, O. HANSSEN, H. HUIJBREGTS, F. LAKATOS, O. MARTIN, Z. NECULISEANU, N.B. NIKITSKY, W. PAILL, A. PIRNAT, V. RIZUN, A. RUICĂNESCU, J. STEGNER, I. SÜDA, P. SZWAŁKO, V. TAMUTIS, D. TELNOV, V. TSINKEVICH, V. VERSTEIRT, V. VIGNON, M. VÖGELI, P. ZACH (2005) Osmoderma eremita (Coleoptera, Scarabaeidae, Cetoniinae) in Europe. Animal Biodiversity and Conservation, 28(1): 1-44.

REDOLFI DE ZAN L., M. BARDIANI, G. ANTONINI, A. CAMPANARO, S. CHIAR, E. MANCINI, M. MAURA, S. SABATELLI, E. SOLANO, A. ZAULI, G. SABBATINI PEVERIERI, P.F. ROVERSI (2017) Guidelines for the monitoring of Cerambyx cerdo. In: Carpaneto, G.M., P. Audisio, M.A. Bologna, P.F. Roversi, F. Mason (Eds) Guidelines for the Monitoring of the Saproxylic Beetles protected in Europe. Nature Conservation, 20: 129-164.

SALAFSKY, N., D. SALZER, A.J. STATTERSFIELD, C. HILTON-TAYLOR, R. NEUGARTEN, S.H.M. BUTCHART, B. COLLEN, N. COX, L.L. MASTER, S. O'CONNOR, D. WILKIE (2008) A Standard Lexicon for Biodiversity Conservation: Unified Classifications of Threats and Actions. Conservation Biology, 22: 897-911.

SCHIEGG, K. (2000) Effects of dead wood volume and connectivity on saproxylic insect species diversity. Ecoscience, 7: 290-298. 
SERAFIM, R (2010) The catalogue of the palaearctic species of Lamiinae (Coleoptera: Cerambycidae) from the patrimony of "Grigore Antipa" National Museum of Natural History (Bucharest) (Part V). Travaux du Muséum National d'Histoire Naturelle "Grigore Antipa", 53: 235-272.

SERAFIM, R., C. CHIMIŞLIU, N.G. LILA (2004) Catalogul Colecţiei de Cerambycidae (Insecta: Coleoptera: Cerambycoidea) din patrimoniul Muzeului Olteniei Craiova. Muzeul Olteniei Craiova. Studii şi Comunicări Ştiinţele Naturii, Craiova, 20: 189-197 (in Romanian).

SIRAMI C., P. JAY-ROBERT, H. BRUSTEL, L. VALLADARES, S. LE GUILLOUX, J.L. MARTIN (2008) Saproxylic beetle assemblages of old holm-oak trees in the Mediterranean region: role of a keystone structure in a changing heterogeneous landscape. Revue Écologie (terre vie), 10: 101-114.

STAN M. (2013) Romanian species of lucanids (Coleoptera: Scarabaeoidea: Lucanidae) in the collections of "Grigore Antipa" National Museum of Natural History. Travaux du Muséum National d'Histoire Naturelle "Grigore Antipa", 56 (2): 173-184.

STAN, M., E. NITZU (2013) New data on the knowledge of beetle fauna (Insecta: Coleoptera) in the "Bârnova-Repedea Forest" site of community importance (ROSCI01235, Iaşi, Romania). Travaux du Muséum National d'Histoire Naturelle "Grigore Antipa", 56 (1): 33-44.

STEFANELLI, S., F. DELLA ROCCA, G. BOGLIANI (2014) Saproxylic beetles of the Po plain woodlands, Italy. Biodiversity Data Journal, 2: e1106.

THOMAS, C. D. (2000) Dispersal and extinction in fragmented landscapes. Proceedings of the Royal Society B: Biological Sciences, 267: 139-145.

TORRES-VILA, LM. (2017) Reproductive biology of the great capricorn beetle, Cerambyx cerdo (Coleoptera: Cerambycidae): a protected but occasionally harmful species. Bulletin of Entomological Research, 11: 1-13.

VREZEC, A., S. AMBROŽIČ, A. KAPLA (2012) An overview of sampling methods tests for monitoring schemes of saproxylic beetles in the scope of Natura 2000 in Slovenia. In: M. Jurc, ed. Saproxylic beetles in Europe: monitoring, biology and conservation. Slovenian Forestry Institute, Silva Slovenica, Ljubljana, pp. 73-90.

ZAPPONI, L., A. CINI, M. BARDIANI, S. HARDERSEN, M. MAURA, E. MAURIZ, L. REDOLFI DE ZAN, P. AUDISIO, M.A. BOLOGNA, G.M. CARPANETO, P.F. ROVERSI, G. SABBATINI PEVERIERI, F. MASON, A. CAMPANARO (2017) Citizen science data as an efficient tool for mapping protected saproxylic beetles. Biological Conservation, 208: 139-145.

*** http://www.natura2000prigoriabengesti.ro/index.php/prezentare-generală

*** Applied biomathematics, 2002- ramas Red List 3.0. Threatened Species Classification Under Certainty (available at: http://www.ramas.com/redlist.htm).

*** EEA, reference grid samples for projection ETRS89-LAEA 52N 10E 2015 (available at: http:// www.eea.europa.eu/data-and-maps/data/eea-reference-grids).

*** ESRI, 2012, ArcGIS Desktop: Release 10.1, Environmental Systems Research Institute, Redlands, CA.

*** HABITAT DIRECTIVE, 92/43/EEC of 21 May 1992 on the conservation of natural habitats and of wild fauna and flora: Official Journal of E.U., 22.7 .92 (L: 206/7): 7-50. (available at: http:// ec.europa.eu/environment/nature/legislation/habitatsdirective/index_en.htm).

*** IUCN, 2010 - IUCN standards and petitions subcommittee. Guidelines for Using the IUCN Red List Categories and Criteria. Version 8.0. Prepared by the Standards and Petitions Subcommittee in March 2010 (available at: http://www.iucnredlist.org/technical-documents/categories-andcriteria/2001-categories-criteria). 